\title{
Arts-therapy as innovative educational strategy for embodied narrative, lifelong learning and inclusion
}

\section{Gabriella Aleandri ${ }^{1}$, Fernando Battista ${ }^{2}$}

${ }^{1}$ Department of Education, Roma Tre University, Italy, ${ }^{2}$ Department of Education, Roma Tre University, Italy.

\begin{abstract}
Art, artistic expression and arts-therapy can be an opportunity to the pedagogy need to develop effective, innovative and avant-garde visions and strategies on issues considered crucial for cohesion and inclusion, in particular regarding migration issue. Dance-movement-therapy is central to this project which is configured as art-based research in the educational / intercultural field. It is a political-pedagogical project starting within the school context to open up to the territory. The research question therefore aims to verify whether arttherapy can create inclusive and intercultural environments, integrate with autobiographical methods through embodied narratives and stimulate selfawareness and lifelong learning. Main aims are: analyzing ways of inclusion, making significant and transformative changes to growth processes, modifying prejudices and stereotypes. The research, moving within the theoretical and methodological framework of the research-intervention, followed a mixed method preserving its qualitative nature, following the phenomenological and hermeneutic approach and, at the same time, using a questionnaire (Pettigrew, Meertens, 1995), which characterized the quantitative part. Among the main results, the discovery of feeling directed towards new perspectives from which to look at the world, more aware and proactive, emerged. Results have strengthened the choice of adopting a such innovative integrated educational strategy for inclusion and lifelong learning.
\end{abstract}

Keywords: Arts-based research; education; embodied narrative; lifelong learning; self-awareness; inclusion. 


\section{Introduction}

Current pedagogical strategies, aimed at lifelong, lifewide and lifedeep education, propose custom paths so that every person is, first of all, entitled to the fundamental right to his/her dignity and his/her value as a human being living in society. The promotion and development of a more inclusive society become crucial in order to understand the real problems affecting marginalization risk people. Making society and politics responsible, conscious and sharer of these problems means increasing the learning and knowledge levels in order to intervene in an effective manner through many tools and concrete actions. Sustainability of inclusion has achieved through political and economic interventions, but also through pedagogical actions aiming to reconstruct the process of personal identity. To achieve an adequate level of social inclusion, it is first of all necessary to overcome the walls raised by stereotyped concepts and prejudices about differences, to achieve an active and supportive participation of all citizens in an intercultural key. In this perspective, therefore, the importance of inclusion is closely connected with that of lifelong learning as it embraces the different all stages of life as well as all its dimensions, including issues relating to discomfort and marginalization. Lifelong education can be argued as a development and a human dignity opportunity promotion, in all its aspects, taking into account the stadial developments and the connatural dynamic social processes. The lifelong and lifewide pedagogy aims therefore to activate cultural, social, ethical as well as cognitive resources to reach a wider inclusion. Education and inclusion are fundamental objectives for each person, with specific experiences, involved in the processes of building identity and personality, which are the basis of pedagogical action. Since the report to UNESCO of the International Commission on Education for the 21st century, the concept of an education aimed at a deep and harmonious development, both personal and social for everyone, is emphasized (Delors, 2000). One of the objectives is to enhance each person's skills to relate to others and to the society. It also consists in giving back to the subject, including migrants, new stimuli, new motivations to re-build a life and re-enter the community and society in a proactive, integrated and inclusive way. The issues of social inclusion and active citizenship prove to be crucial in the processes of reflection on democracy and its implementation, understood as a fundamental part of culture and as a lifestyle, which aim to make the person more active, supportive and cooperating. Another goal is to raise awareness of the process of recognizing and promoting diversity, as a value and mutual enrichment. Programs of inclusion can be carried out through educational strategies that aim above all at the knowledge of oneself, of one's body, of one's experience, of the context through which practices of cultural participation are implemented. Through the analysis of the body, sometimes blocked by difficult and / or painful situations, we can go further, towards the development of infinite and new expressive and communicative possibilities. Through arts therapies and specifically dance movement therapy, each person can reach an in-depth understanding of himself, of his 
experiences, of interpersonal relationships, of the significant educational experiences undertaken and to be undertaken, of his own growth path. Through the analysis of one's own experience, according to autobiographical methods as pedagogical and educational tools (Josso, 1991; Pineau \& Le Grand, 1993; Demetrio, 1996; Alberici, 2000; Dominicè, 2000; Cambi, 2002; Formenti, 2009, 2017; Aleandri, 2012, 2015, 2017, 2019, 2020), each person can enhance significant experiences lived in the broadest areas, especially from an educational and relational point of view. That is useful to find "threads" and a more organic self-orientation, essential for planning own present and future in a positive and proactive way. Person's uniqueness and past experiences consideration are crucial from a pedagogical point of view, as a source to draw from in order to re-build and re-design the identity process, fundamental to be recognized in an increasingly fragmented society, in order to orient or reorient, to gain a greater one's own and others' awareness. The analysis of the context, through observation and autobiographical narration, allows to understand the culture, traditions, needs, etc. In this way it is possible to plan personalized, but also collective paths, through educational actions that stimulate the process of lifelong education. "In such a perspective aimed at lifelong and lifewide learning and education, the call is aimed not only at soliciting and spreading this approach as a 'social practice' (and socializing) and widespread individual behavior, but also and above all as a lifestyle, philosophy of life, shared and internalized culture aimed at a better quality of life and the well-being of both people and society" (Aleandri, 2012, 15). Within this pedagogical action it ia possible leading people from marginalization to new perspectives of commitment and personal growth, first of all with themselves and then towards others, as a real inclusive dimension. For this reason, a pedagogical approach oriented to lifelong learning and education aims to enhance any kind of education, from the formal one to the non-formal and informal one. It will allow to turn the experiences of every individual into a growth opportunity, in the continuous development process aimed to outline one's own identity. It means also its primary relational and social connotation. In such scenario, therefore, an education, oriented not only to allow each one to develop one's own creative vocational and innovative potential but also to achieve full equality and social inclusion, takes shape.

\section{The research project}

The research takes shape within a secondary school in the eastern suburbs of Rome to reflect on migratory phenomena, which in these times undergo very rapid changes, and on the political and ideological influences that pollute information and consequently feed fears and discrimination. These conditions affect the education of students around the world. In a society where differences often become an element of marginalization, we wanted to deepen the relationship between education, prejudice, inclusion, and artistic expression, in particular with the body and dance. The project developed in collaboration with the Department of 
Education of Roma Tre University, the school Liceo Amaldi in Rome and Intersos-Italy. The research-intervention aims at verifying the effectiveness of the use of artistic languages within an educational context, in relation to the migratory phenomenon and the consequent prejudice. The research focused attention on the context and on the participants. The concrete action was carried out with artistic proposals, concerning dance, the body and the languages of art, which favored reflection, comparison and relationships. The researchers and the participants themselves exercise observation and active listening to realities or imaginaries in the making, and the arts act as a narrative and language tool to promoting knowledge and the exchange of emotions. The research named "Pedagogy of the Border" is inspired by Henry Giroux's definition according to which what can perhaps improve and better promote intercultural competence are invitations to engage in "border crossings" (Giroux, 1992). The act of crossing borders helps students develop intercultural competences and skills that enable them to live together consciously beyond differences. Therefore, it is necessary to establish pedagogical conditions for which students become border crossers in order to understand otherness and further generate borderlands in which the different cultural resources allow growing new identities (Idem). The research aims to bring together and make known migrants and adolescents through dance movement therapy, the body, embodied narrative and the performing arts, to educate people to a cooperative spirit, to mutual respect to achieve individual well-being within a community growing in differences. Starting from the body, the substance of our being and the place of our identity, a slippery body for everyone, a body in transformation for adolescents, a tortured, mortified, abused body for migrants mean being able to use universal expressiveness where no one is advantaged. A Pedagogy of the Border is therefore configured as a non-place (Auge, 2009), free from signs of power and belonging. Migrants and adolescents have similar needs such as identity, autonomy, self-esteem, etc., and similar characteristics such as transition, sense of belonging and identity. Dance is a tool for well-being and care and it is proposed as a bridge between cultures, framing the friendship between those who are "foreign to the other".

\subsection{Participants}

The participants were 30/35 people in total per meeting, of which 14 students and 15 migrants, 2 tutor teachers and 3/4 among cultural mediators, psychologists and Intersos-Italia operators. Students are 17-18 years of age, migrants are aged between 17 and 25 .

\section{Methods, aims and tools}

The research followed mixed methods, preserving its qualitative nature following a phenomenological and hermeneutic approach, and integrating it with a quantitative device deemed appropriate to the reflections and the nature of the research, a questionnaire about prejudice (Pettigrew and Meertens 1995) filled out by students, before and after the scheduled 
workshop meetings. The research is an Art-Based Research (ABR) (Barone \& Eisner, 2011; Knowles \& Cole, 2008; Leavy, 2009) that is, a research that uses arts, in a broad meaning, to explore and eventually challenge human action and experience (Savin-Baden, 2014). Priority is given to the artistic process, the main tool through which to live and observe the experience by the participants, including the researcher (McNiff, 2012). As regards the qualitative investigation tools, the following were used: the semi-structured phenomenological interview (Larkin et al., 2006; Zammuner, 2015), the focus groups (Lucisano \& Salerni, 2018), the participant observation and the logbooks (Benvenuto, 2015) witten by the students and tutor teachers. The general purpose of the research-intervention, which we can define as immersive, consists in reflecting and analyzing how a very particular experience of Border Pedagogy can contribute to:

- transform a distorted information-media paradigm into an emancipativeevolutionary one based on direct knowledge of people and their lives towards lifelong, lifewide and lifedeep learning perspective;

- favor a transformation of prejudice in the context and a mature and responsible growth of adolescents;

- $\quad$ contribute to deconstructing stereotyped conceptions;

- form new imaginaries with which to look at reality; build a critical and rhizomatic thinking away from toxic narratives (Fiorucci, 2019).

\section{Main results}

The research took into consideration, in general, some concepts or categories (Gianturco, 2004). These are indicators of psychocorporeal and intercultural development identified in the process of building the project, then integrated by the analysis and coding of focus groups and semi-structured interviews. We can therefore indicate as categories:

- Evolutionary processes and the body-mind relationship in psychocorporeal development - An intercultural challenge, a body among bodies.

- Process of emotional and identity growth - Create relationship and intercultural baggage.

- Intercultural training needs - Art as a way of learning and exploiting diversity against toxic narratives. A postcolonial reinterpretation.

- Community learning - Getting to know each other through corporeality and art.

- Access and development of critical thinking - Look at the kaleidoscope, divergent mind against prejudice. 
- Empathic relational area - Creating bonds.

In particular, we highlight the categorization relating to the process of emotional and identity growth which also indicates the impact on the level of self-esteem of the participants. In this area, which includes emotional growth and a greater definition of identity, the group has grown, as a whole, and has transformed. Among the variables investigated, it is interesting to highlight how solidarity is increased at the end (out) of the educational intervention compared to the beginning (in) (Fig. 1):

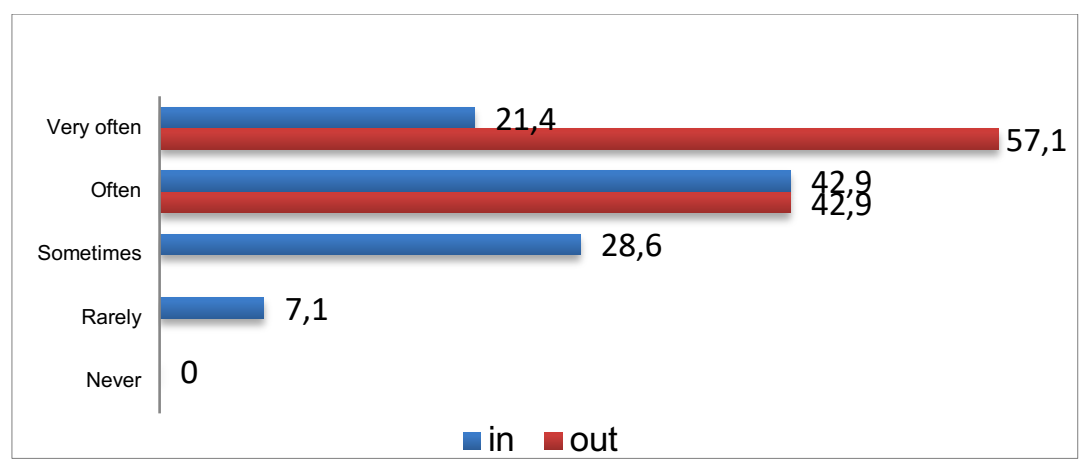

Figure 1. How often have you felt solidarity with migrants who live here?

The main increased response corncerns feeling solidarity very often, which grew from $21.4 \%$ to $57.1 \%$, and has become the response with the highest percentage.

The greater confidence in using the workspace and in the interpersonal relationships, the possibility of using the body in gradually less stereotyped forms - verified following the indications of the observation of Laban analisys (Laban, 1999), and found by the checklists compiled tutor teachers - allowed them to acquire greater self-confidence by dealing with otherness. Changes related to life choices are also important, in particular those highlighted by some students attending the laboratory in 2017 and recently interviewed for research. It was perhaps the area richest in results, it has aroused various reflections on how much and how art can convey growth paths which then turn out to be authentic transformations of the life project. Some testimonies of participants student and migrant people are following:

- Before living with people, for example with Italian boys, it was difficult for me. Living together, we change things in our lives, it is what I was looking for and I found here.

- Thanks to this activity I am coming to realize what I want to do when I grow up. I want to take Law Degree to help those people (migrants), to give them a voice in this society. 
- When we listened the stories of each of them, that entered your soul, it make you understand how much today's society gives more space to prejudice than humanity, to how much you believe more about what it is told by the media or by people not informed about. Why are we so uninformed and presumptuous? This experience awakened in me the desire to trust people, awakened me from the coma of disinformation, made me understand the real extent of everyday problems compared to the often more difficult ones that migrants face.

\section{Discussion and perspectives}

One of the issues emerged within the results concerns the discovery of feeling lead to a new perspective, a new point of view from which to look at the world. The empathic response that placed the students in front of identifying themselves in those situations of discomfort and separation is relevant. It is, indeed, in such conditions of discomfort that we can find ourselves in an exotopic condition and which in fact questions one's "human condition" as Arendt (1958) would say, a disorientation and imbalance that produces an important step towards a reflective attitude on one's own to be and on their own thoughts.A decentralization / discovery confusing and exciting that concerns the identity processes and which, avoiding essentialism, can be experienced in a social context, in interacting processes where different identities are writing (Bhabha, 1994). This enhances us to reflect on writing and "on the hands that write to us", and allows us to develop ways and thoughts independent of the dominant matrices and, consequently, to change our way of "writing" (Surian \& Mahmoud, 2019) and imagine or continue to imagine their life project from this observation point. This allows you to reposition yourself within your own being with a greater awareness of a vision connected to a reality that does not come from information or rumors, but from a direct source, from a shared and authentically inclusive life experience. Finding a time to reflect on the experience has allowed us to be more aware of our own existence, and in several cases to reformulate projects, dreams or simply look to the future with different eyes from a lifelong, lifewide and lifedeep learninig perspective.

\section{References}

Alberici, A. (2000). Educazione in età adulta. Percorsi biografici nella ricerca e nella formazione. Roma: Armando Editore.

Aleandri, G. (2012). Scritture adulte. L'autobiografia come ricerca e costruzione del sé. Roma: Armando Editore.

Aleandri, G. (2015). Autobiographical methods for broader lifelong and lifewide learning for all: A research based on original format. Procedia - Social and Behavioral Sciences, 191, 352-356. 
Aleandri, G. (2017). Scritture di una vita. Scritture per... Un sottoprogetto. QDS-Quaderni di Didattica della Scrittura, 28, 115-125.

Aleandri, G. (Ed.). (2019). Lifelong and lifewide learning and education: Spagna e Italia aconfronto. (Vol. 5). Roma: Roma TrE-Press.

Aleandri, G. \& Consoli, E. (2020). Metodi autobiografici e coding per lo sviluppo dell'autoconsapevolezza e delle competenze trasversali. Journal of Educational, Cultural and Psychological Studies, 20, 275-300. doi: https://dx.doi.org/10.7358/ecps-2020-021alea

Arendt, H. (1958). The Human Condition. Chicago: University of Chicago Press.

Benvenuto, G. (2015). Stili e metodi della ricerca educativa. Roma: Carocci.

Bhabha, H.K. (1994). The location of culture. London: Routledge.

Cambi, F. (2002). L'autobiografia come metodo formativo. Roma-Bari: Laterza.

Delors, J. (2000). Nell'educazione un tesoro. Tr. it. Roma: Armando Editore.

Demetrio, D. (1996). Raccontarsi. L'autobiografia come cura di sé. Milano: Cortina.

Dominicé, P. (2000). Learning from our lives: Using educational biographies with adults. San Francisco: Jossey-Bass.

Fiorucci, M. (2020). Educazione, formazione e pedagogia in prospettiva interculturale. Milano: Franco Angeli.

Formenti, L. (2009). Attraversare la cura. Relazioni, contesti e pratiche della scrittura di sé. Trento: Erickson.

Formenti, L. (2017). Complexity, adult biographies and co-operative transformation. In S. W. Marcella Milana (Ed.), The Palgrave international handbook on adult and lifelong education and learning. London: Palgrave Macmillan.

Gianturco, G. (2004). L'intervista qualitativa. Dal discorso al testo scritto. Milano: Angelo Guerini e associati.

Giroux, H. (1992). Border crossing: Cultural workers and the politics of education. New York: Routledge.A.L.

Josso, C. (1991). Cheminer vers soi. Lausanne: L'Ade d'Homme.

Knowles, J. G., \& Cole, A. L. (2008). Handbook of the arts in qualitative research: Perspectives, methodologies, examples, and issues. Los Angeles, CA: Sage.

Laban, R. (1999). L'arte del movimento. Macerata: Ephemeria.

Larkin, M., Watts, S., \& Clifton, E. (2006). Giving voice and making sense in interpretative phenomenological analysis. Qualitative Research in Psychology, 3:102-120.

Leavy, P. (2009). Method meets art: arts-based research practice. New York, NY: The Guilford Press.

Lucisano, P., \& Salerni A. (2002). Metodologia della ricerca in educazione e formazione. Roma: Carocci editore.

McNiff, S. (2008). Arts-based research. In J.G. Knowles \& A.L. Cole (Eds), Handbook of the arts in qualitative research: perspective, methodologies, example and issues. Thousand Oaks: Sage Publications. 
Pettigrew, T. F., \& Meertens, R. W. (1995). Subtle and blatant prejudice in western Europe. European Journal of Social Psychology.

Pineau, G. \& Le Grand, J. L. (1993). Les histoires de vie. Paris: PUF.Barone, T., \& Eisner, E.W. (eds.) (2012). Arts based research. Los Angeles: Sage Publications.

Savin-Baden, M. (2014). A Practical guide to arts-related research. Rotterdam: Sense Publisher.

van Foerster, H., \& Bernhard, B. (2001). La verità è l'invenzione di un bugiardo. Colloqui per scettici. Milano: Meltemi Editore.

Zammuner, V. L. (1998). Tecniche dell'intervista e del questionario. Bologna: il Mulino. 